\title{
DIE EERSTE BEGINSELS VAN DIE WOORD, DIE IMPLIKASIE VAN HEB 5:12 VIR KERK EN TEOLOGIE
}

\author{
Benno A Zuiddam \\ Skool vir Bybelwetenskappe \& Antieke Tale \\ Noordwes Universiteit, Potchefstroom
}

\begin{abstract}

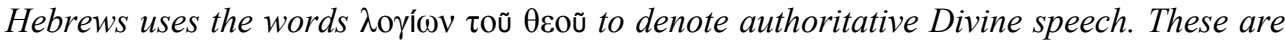
treated as oracles from heaven with an inherently divine quality. Hebrews' use of $\lambda$ oyív as such implies a divine source and this is reinforced by toũ $\theta$ coũ. Both the wider and narrower context of Hebrews 5:12 show that this expression is used in a context of revelation. God reaches out and speaks. In this context God's oracles are presented as instrumental for maintaining this relationship with the divine and particularly portrayed as promoting spiritual growth and maturity. It is from this literary context, and the specific

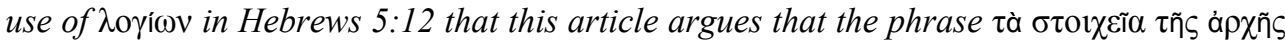

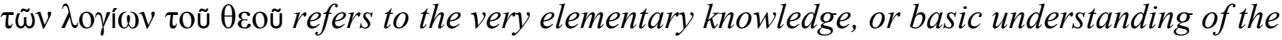
"Word of God" or his collective "Oracles". Even the practice of these Oracle-basics is considered potentially life-changing and spiritually empowering by the author of Hebrews. Knowledge of God's revelation, even a thirst for more, is presented as a basic requirement for Christian life.
\end{abstract}

Keywords: Oracle, Bible, Hebrews 5:12, Bible Translation, Revelation

Sleutelwoorde: Orakel, Bybel, Hebreërs 5:12, Bybelvertaling, Openbaring

\section{Inleiding}

Dat God praat met mense en sy wil openbaar, speel 'n baie belangrike rol in die brief wat in die vroeë Kerk bekend gestaan het as "die brief van die Apostel Paulus aan die Hebreërs." Dit bereik 'n hoogtepunt in Heb 5:12, waar die skrywer die stelling maak dat hy by gelowiges 'n basiese kennis van God se geopenbaarde Woord veronderstel. In die Grieks

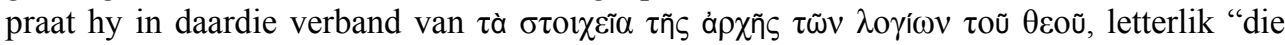
eerste beginsels van God se orakels" of "die basiese beginsels van die geopenbaarde Woord van God".

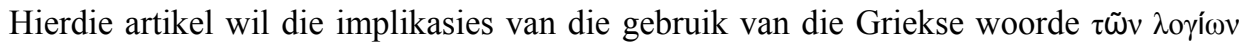

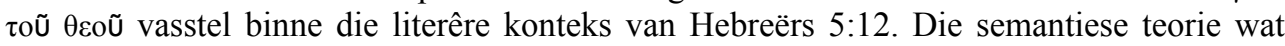
hierby gebruik word, is die filologiese benadering, wat die teks vanuit sy grammatiese en literêre konteks probeer verstaan. Uit daardie verstaan word betoog dat die huidige Afrikaanse vertalings van die teks verbeter kan word, angesien die wesenlike betekenis

Hoewel daar nie persoonlike groete aan die begin van Hebreërs is nie, wys Nestle-Aland (1988:587) daarop dat 'n groot verskeidenheid van tekstradisies en die oorgrote meerderheid van handskrifte Hebreërs reg vanaf die begin beskou het as ' $n$ brief en ten minste die tradisionele brief-aanduider $\pi \rho \circ \varsigma$ \& $\beta \rho \alpha 10 u \varsigma$ ingesluit het. Indien dit nie alles deel was van die oorspronklike nie, dan wys dit hoe die vroeë kerk die dokument ontvang het. Nestle-Aland (1988:587) haal Papirus 47 aan as argument om die briefaanhef uit te los, maar dit is juis hierdie Chester Beatty-papirus wat Hebreërs toereken tot die briewe van Paulus en dit tweede in die lys stel as brief van hierdie apostel, na Romeine (Guthrie 1990:670). 


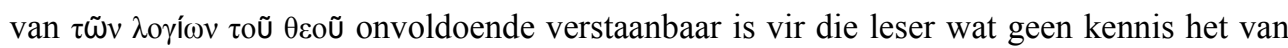
die Grieks nie.

- Die 1933/53-vertaling:

Want hoewel julle vanweë die tyd leraars behoort te wees, het julle weer nodig dat 'n mens julle die eerste beginsels van die woorde van God moet leer, en julle het weer behoefte aan melk en nie aan vaste spys nie.

- Die 1983/92-vertaling:

Hoewel julle teen hierdie tyd self reeds onderrig behoort te gee, het julle weer nodig dat iemand julle in die grondwaarhede van die woord van God moet onderrig. 'n Mens moet julle met melk voed en nie met vaste kos nie.

- Die Nuwe Lewende Vertaling (2006):

As 'n mens dink aan hoe lank julle reeds Christene is, moes julle eintlik al self onderrig in die geloof gegee het. En nou het 'n mens werklikwaar weer nodig om julle die mees elementêre aspekte van die woord van God te leer! Julle is soos babatjies wat nog net melk kan drink en nie vaste kos kan inneem nie.

Die ou vertaling is letterliker as die nuwe, en laasgenoemde meer bron-gerig as die NLV, maar by nie een van die drie kom die bedoeling van die skrywer tot uitdrukking wanneer hy praat van "die woorde van God" nie. Vir die Afrikaanse leser lyk dit of hy praat van "woorde" van God wat in die Grieks net sowel $\lambda$ ó geval nie. Die skrywer gebruik bewustelik 'n seldsame woord wat 'n mens net enkele male in die Nuwe Testament kry: $\lambda$ ó $\gamma \mathbf{} \alpha$. Die ander plekke waar dit voorkom in die Nuwe Testament is Hand 7:38, Rom 3:2 en 1 Pet 4:11. Hierdie woord handel nie oor spiritualiteit of geloofstradisies van mense nie, maar is in essensie 'n orakel, 'n Godsspraak wat die mens net ontvang en deurgee.

Dis belangrik om te besef dat daar 'n ingrypende verskil bestaan tussen $\lambda$ ó $\gamma$ lov "orakel" (vgl. NRSV: "the basic elements of the oracles of God") en die meer algemene $\lambda$ ó $\gamma$ o "woord". Dit het verskeie implikasies vir hoe die Bybelskrywers en vroeë Christene hulle heilige Skrifte gesien het: "One of the most evident ways that the writers of Biblical literature claimed to receive divine speech is their use of the word $\lambda$ ó Rensburg \& Jordaan 2008:381). ${ }^{2}$

Hierdie woord $\lambda$ ó $\gamma$ ıv is 'n letterlike voorbeeld van Jesus se verklaring oor die verwydering of toevoeging van 'n tittel of ' $n$ jota ${ }^{3}$ aan die teks van die Skrif, wat aangee dat die uitspraak sowel op filoloë as op die algemene publiek van toepassing mag wees. Die algemeen gebruikte $\lambda$ ójo kom algemeen voor en beteken gewoonlik “woord," 'n kommunikasiedraer

2 Die goddelike gesag van $\lambda$ ó $\gamma$ ıov is reeds veronderstel in die woord self, aangesien dit altyd 'n goddelike bron impliseer. Die woord 'orakel' of 'Godspraak' is van toepassing. Koester (2005:301) brei uit daarop:

“'Oracles' (logioi) were prophetic utterances, including the sayings of God found in Scripture (Philo, Posterity 28; Unchangeable 50). The plural commonly referred to the Law (Deut 33:9-10, Acts 7:38; Philo, Moses 2.56; Decalogue 36; cf. Ps 119:10-11, 102-3, 162-63) or Jewish Scriptures (Moses 2.188; Ep. Arist. 176-77; Rom $3: 2$; I Clem. 53:1; 62:3). The term "oracles" is appropriate because Hebrews takes the Scriptures to be divine speech and interprets them in light of Christ (pp. 117-18). The basic elements of God's oracles (Heb 5:12) and the basic word of Christ (6:1) are not identical, but neither can be taken without the other."

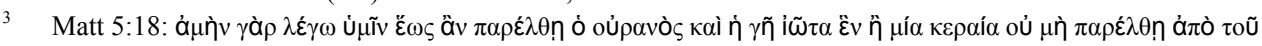

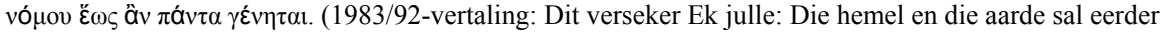
vergaan as dat een letter of letterstrepie van die wet sal wegval voordat alles voleindig is.) 


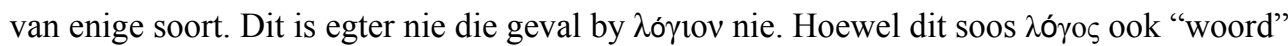
beteken, is dit in 'n heel bepaalde sin met 'n beperkte betekenisveld. Die ou Grieke het dit eksklusief gebruik vir 'n orakel (vgl. Liddell \& Scott 1996:1056), oftewel 'n gesaghebbende uitspraak of aanwysing van die gode. Die $\lambda$ ó $\gamma$ เov kom volgens die Griekse taalgebruik dus noodwendig uit die hemel. "In other words, while the author of $\lambda$ ó $\gamma \circ \varsigma$ could be human or divine, $\lambda$ ó $\gamma$ ıov was always produced in the heavenlies" (Zuiddam, Van Rensburg \& Jordaan 2008:381). ${ }^{4}$

Hebreërs 5:12 handel dus nie oor bloot woorde nie, maar oor Godspraak of orakels. Dit gaan oor openbaringswoorde. Die meervoud met die gebruik van die lidwoord dui aan dat dit gaan om 'n versameling of die verskynsel van Godspraak. Die goddelike oorsprong word dan nog verder versterk deur $\tau$ oũ $\theta$ coũ. Dit is nie sommer orakels uit die hemel nie, maar hulle kom van die enige ware God af wat homself reeds sedert die Skepping aan die mens openbaar. Die konteks binne Hebreërs, met name die vier hoofstukke wat 5:12 voorafgaan, is in die verband van belang, o.m. aangesien die eerste vier hoofstukke van Hebreërs uitgebreid aandag gee aan God wat deur die geskiedenis heen gepraat en inligting aan die mensheid geopenbaar het.

Hierdie artikel argumenteer dat 'n nuwe Afrikaanse Bybelvertaling die goddelike openbaringskomponent van $\lambda$ ó $\gamma$ $\alpha$ as sulks moet verreken, asook die bevestiging en versterking daarvan in die literêre konteks van Hebreërs.

Die doel is om binne hierdie konteks vas te stel wat die skrywer in gedagte het as hy

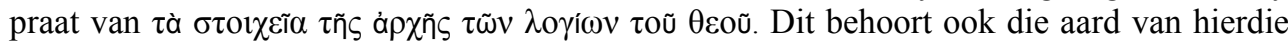
$\lambda o ́ \gamma 1 \alpha$ te verduidelik en die gesag wat die outeur toeken aan hierdie Godsprake. Met gebruik van die filologiese metode sal eers (1) die wyer konteks van Hebreërs onder die aandag kom (2) en vervolgens onmiddellike konteks (3) van Hebreërs 4:14-5:14, met name die $5: 11-14$. Vanuit hierdie konteks vind eksegese plaas van Hebreërs 5:12 en die rol van $\tau \tilde{\omega} v$

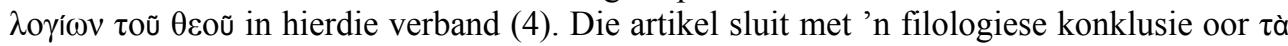

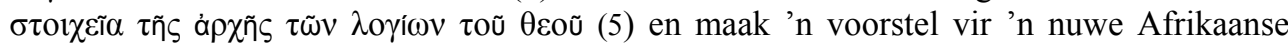
vertaling.

\section{Openbaring as wyer literêre konteks in Hebreërs}

\section{God wat kommunikeer}

Die eerste hoofstukke van Hebreërs maak baie van die Woord van God en die verskynsel dat God praat en uitreik na mense. Volgens die outeur soek God 'n regte verhouding met die mens. Hy gee baie aandag aan God se plan om sondige mense weer in 'n regte verhouding tot Hom te bring en te versoen. Openbaring is die instrument om dit te bewerkstellig. Om daardie rede het God met die mensheid begin praat, op verskeie maniere, ook deur allerhande profete in sy diens te gebruik. Jesus word voorgestel as God se uiteindelike instrument van openbaring en word die Seun van die Allerhoogste genoem (1:1-3). ${ }^{5}$ Die woorde van Jesus verdien die aandag van die mensheid, meer nog as die openbaring aan Moses vir die volk Israel, hoewel in daardie geval dit nogal bemiddel is deur engele (2:1-3, vgl. Hand 7).

4 Die $\lambda$ ó $1 \alpha$ is niks minder as Goddelike openbaring en kommunikasie nie, wat Moses en die Profete en Apostels as tussengangers gebruik het, soos Apollo en sy Pythia in die Griekse religie. Volgens die skrywer gaan dit om geopenbaarde Godspraak. Vgl. Boice (1991:276), Dunn (1988:130-131), Fitzmyer (1993:326) en Lekkerkerker (1962:118).

5 Die HERE wat praat het 'n sentrale rol in die eerste vier hoofstukke van Hebreërs (1:1-4:13) en dien as 'n strukturele merker. Vgl. Karrer (2002:224), Schunack (2002:21-59). 
Nogtans, die respons op God se openbaring was, volgens die skrywer van Hebreërs, nie al te goed nie. Die volk het gesukkel om gehoorsaam te wees aan die Here se stem (3:7), en die outeur verbind daardie ongehoorsaamheid met 'n gebrek aan vertroue in die Woord van God (3:19-4:13). In die lig van hierdie konteks moet ook die outeur se oproep en verwyte in Heb 5:12 verstaan word. Vir 4 hoofstukke lank verduidelik hy die grootheid en die belang van God se geopenbaarde Woord, teologies en in die geskiedenis. Eers wanneer hy sy lesers deeglik laat kennis neem het van die openbaringsfeite, konfronteer hy hulle in Heb 5:12. Ook hulle moet nadergetrek word aan die stem van God en weer mooi begin luister.

Hierdie tema van openbaring - God wat praat en die mens nader probeer trek - kry baie aandag in die eerste hoofstukke van Hebreërs en bereik 'n voorlopige hoogtepunt in Hebreërs 4:12-13, wat die kwaliteite van die Woord van God ${ }^{6}$ aanprys. Dit is juis voordat die outeur Christus beskryf as 'n hoëpriester wat gelowiges met God versoen en hulle vertroue werd is.

Hebreërs 4:12-13 is van groot belang om die outeur se siening van die Woord van God as sentrale instrument binne daardie verhouding van God en mens te verstaan. Volgens hom is elke mens rekenskap en gehoorsaamheid verskuldig aan God. Met ander woorde: elke mens moet na Hom luister en God se openbaring ontvang. Sy Woord is lewend en kragtig en maak 'n verskil. Vir die verstaan van hemelse openbaring in Hebreërs is dit van belang om die karaktereienskappe wat die outeur opsom in Heb 4:12-13, kortliks te bespreek:

1) In die eerste plek is die Woord van God, volgens hom, lewend. Spicq (1977:89) toon aan dat dit veroorsaak word en handel oor 'n goddelike krag wat met hierdie Woord saamkom (Deut 32:47, Matt 13:3; vgl. Laubach 1967:93). Met ander woorde, dit is vreeslik belangrik om te besef dat die skrywer geen magiese woorde in gedagte het nie. Dit is nie ' $n$ klomp towerspreuke nie, maar hulle krag is afhanklik van die aktiwiteit van die God wat handel op die Woord. (Vgl. Bette e.a. 1988:77, Karrer 2002:226 en Van Oyen 1962:65.)

2) 'n Tweede karaktereienskap van Woordopenbaring in Hebreërs is dat dit krag besit en 'n praktiese verskil kan maak. "Dit is "kragtig", dit is energiek, vol aktiwiteit, m.a.w. dit bly werksaam in 'n volle mate," verduidelik Fensham (1981:39). Dit word sigbaar in die gevolge, in wat gebeur nadat God sy Woord gespreek het. (Vgl. Bette 1988:77 en Van Oyen 1962:65.) Hierdie kragtige Woord ondersteun die Christen met die oog op 'n heilige lewe. Laubach (1967:93) verwys in die verband na "der "Wirksamkeit", grie enérgeia, Jesu Christi (Phil 3,21), die sich als umwandelnde Kraft Gottes nicht nur in unserem Heiligungsleben, sondern noch viel stärker in der Umgestaltung unseres irdischen Leibes in den Herrlichkeitsleib ausweisen wird."

3) 'n Derde aspek van Woordopenbaring is dat dit nie net met krag kom nie, maar dat daardie krag doeltreffend aangewend word. Die beeld van 'n swaard is ter sprake. Die

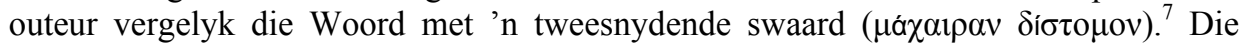

$6 \quad$ In Hebreërs is dit die Heilige Gees wat die Skrywer is van die Woord van God. Hegermann (1988:105) het dit reeds aangetoon: "Im übrigen schließt der Verfasser hier zugleich die in 3,7 begonnene Paraklese ab, unter Aufnahme der Motive des Heiligen Geistes als Sprecher des Wortes $(3,7 \mathrm{a})$ und des herzens als des Ortes verborgener Gefahr für das Heil $(3,12)$."

$7 \quad$ Karrer (2002:227) stel voor dat $\mu$ á $\chi \alpha \iota \rho \alpha v$ gewoonlik vertaal moet word as "Schlachtmesser" in teenstelling met "xiphos" en "rompheia" is sonder grond in die Grieks en mislei die leser. Má $\chi \alpha \iota \alpha$ is 'n algemene verwysing na "swaard" (bv. Gen 34:26 (LXX), Matt 26:47, 55, Mark 14:47, Hand 12:2, 13:14), en kan ook as 'n metafoor gebruik word (Rom 8:35, 13:4). Om bv. "die swaard van die Gees" in Ef 6:17 te vertaal as "die slagtersmes van die Gees" is onvanpas en selfs belaglik binne die konteks van gelowiges wat die wapenrusting van God moet aantrek. Geeneen van die belangrike Bybelvertalings ondersteun sy siening van Heb 4:12 nie. As 'n algemene woord vir swaard, is daar in $\mu \alpha$ a $\chi \alpha 1 \rho \alpha$ 'n verband met Jes 49:2, aangesien die profeet 
uitdrukking kry 'n mens in Psalm 149:6 (vgl. Op 1:16, 2:12), maar die beeld van 'n skerp swaard wat met die Woord van God vergelyk word berus op Jesaja 49:1,2 (LXX):

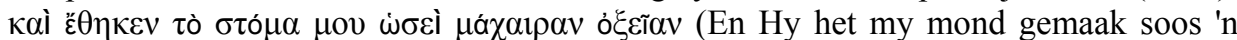
skerp swaard), vgl. Hosea 6:5, Efesiërs 6:17. Dat 'n swaard skerp is en kan steek, toon dat die Woord van God die mens kan raak en deurdring tot sy wese, vgl. Bette e.a. (1988:77), ook Openbaring 2:16. Laubach (1967:94) benadruk in hierdie verband tereg dat die Woord van God eers die lewe van die gelowige self aanraak voordat hy in staat is om die standaarde daarvan effektief aan ander te kan kommunikeer.

4) 'n Vierde aspek van God se Openbaringswoord is dat dit bekwaam en geregtig is om te oordeel. God is die regter van die mens se gedrag en denke. Omdat die mens rekenskap gee aan God, is die Woord van God die maatstaf wat hom help om sy gehoorsaamheid prakties te meet (Van Oyen 1962:67). Die Woordopenbaring kom van 'n alwetende Skepper (Laubach 1967:96) ${ }^{8}$ wat kommunikeer en aan wie die hele mensheid verantwoording verskuldig is. ${ }^{9}$ Die Woord het gesag om sy inherente krag en inhoud, maar ook om sy gesaghebbende Bron, as die stem van God. Die outeur waarsku die lesers om gehoorsaam te wees aan die stem van God en om in te gaan in die rus wat Hy voorsien. Christus verkry vir die mens vrede met God en rus van menslike pogings om uit te reik na God en vir Hom aanvaarbaar te word. Dit is in hierdie konteks dat die kwaliteite van die Woord van God nader omskryf word. ${ }^{10}$

Die Openbaringswoord van God klink ook deur sy Seun. Binne Hebreërs 4:14-5:14, en 5:12 (wat 'n besondere aandag kry in hierdie artikel) vestig dit 'n konteks van Christus wat as hoëpriester die uiteindelike offer vir die versoening van sondes gebring het (4:14-10:22). Die laaste hoofstukke behandel die respons van die mens, met die geloofshelde van vroeër as voorbeeld en uiteindelik praktiese oproepe tot geloofsgehoorsaamheid vir die leser $(10: 23-13: 25)$.

Daar is dus dwarsdeur die brief 'n duidelike struktuur waarin God se openbaring 'n baie belangrike plek inneem. Hierdie openbaringsstruktuur lei na 'n praktiese hoogtepunt vir die gelowige in die versoening in Christus, deur wie God ook gepraat het en die leser lei op die pad van geloofsgehoorsaamheid.

die woord gebruik. Dat 'n swaard ter sprake is en nie 'n offermes nie, word versterk deur die verwysings in

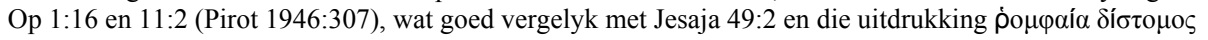
het.

8 In Hebreërs word God self beskou as die outeur van sy Woord. Daar is 'n lewende verbintenis. Die Here handel en tree op volgens sy Woord. In die apostel se beskouing gaan dit dus nie oor 'n inspirasieteorie nie, maar om die Outeur wat praat omdat hy 'n persoonlike verhouding met sy mense soek. Bette e.a. (1988:77) ondersteun hierdie siening: "In het vorige vers werd het Woord van God reeds gepersonifieerd; het Woord leeft, is werkzaam, dringt door, beoordeelt. In dit vers vinden we een overgang van Gods Woord naar God zelf."

9 In Hebreërs is al die mense op aarde rekenskap verskuldig aan God, veral die wat die voorreg gehad het om die Woord van God te ontvang. Laubach (1967:96) is reg as hy sê dat hierdie basiese konsep in Hebreërs Jode sowel as heidene betref: "Damit wendet sich der Apostel noch einmal dem Grundgedanken zu, der ihn in den voraufgegangenen Überlegungen geleitet hat. So wie die Israeliten sind auch die Glieder der Gemeinde dem Herrn Rechenschaft darüber schuldig, was sie mit dem offenbarten Wort in ihrem leben getan haben (vgl Hbr 2,2-3 met Mt 25, 15.19)."

10 Die definisie ó $\lambda$ ó God wat kommunikeer in staat is om op elke mens se omstandighede te reageer aangesien hy sien wat alles aangaan. Dieselfde gedagte kry 'mens ook in die beeld van die tweesnydende swaard, wat altyd sny, watter kant dit ook slaan. 


\section{Die gelowiges moet openbaringskennis kry}

Die lesers word ernstig aangemoedig om meer gevorderde onderwys in die Woord van God te ontvang (5:8-10, vgl. ook 6:1-3). Dit is binne die konteks van hierdie vermaning dat die apostel kwaai raak met hulle. Sy lesers moes op hierdie stadium al baie verder gevorder het. Daar is basiese goed wat hulle nog nie eers mooi verstaan nie. Hulle moet eintlik terug kleuterskool toe, terug na die eerste beginsels van dit wat God geopenbaar het. Hy vergelyk sy lesers met babas wat nog nie vaste kos kan verdra nie (5:13-14) en moedig hulle op daardie wyse aan om nie onvolwasse te bly nie maar om belang te stel in verdere onderrig.

Die skrywer wou uitgebrei het oor die ewige karakter van Jesus se priesterskap volgens

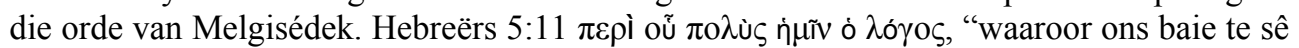
het". Maar ongelukkig kan sy lesers dit nog nie hanteer nie. Die perikoop vertoon groot inhoudelike ooreenkoms met 1 Korintiërs 3:1-4. Hulle is nie gevorderd genoeg nie. Dit is te "moeilik" (5:11), 'n uitdrukking wat net hier in die Nuwe Testament voorkom

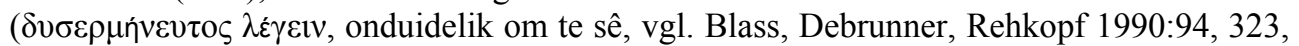
324). Die lesers het nog nie die gewenste vlak bereik om die gevorderde inligting te kan verstaan nie. ${ }^{11}$ Die skrywer raas met hulle. Sy lesers het hardhorend geword, $\dot{\varepsilon} \pi \varepsilon \grave{l} v \omega \theta$ poì

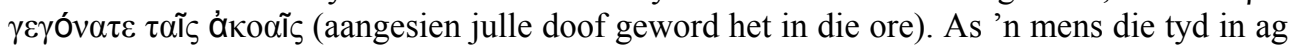
neem vandat hulle Christene geword het, moes hulle al in staat gewees het om ander te onderrig. Maar noudat dit nie die geval was nie, moes hulle maar liewers weer opnuut in $\tau \grave{\alpha}$

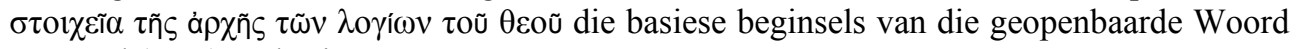
van God (5:12) onderrig ontvang.

Dit is in hierdie konteks dat die outeur sy lesers vergelyk met baie klein kindertjies. Hulle is soos babas wat net melk kan verdra en geen vaste kos kan hanteer nie. Hebreërs

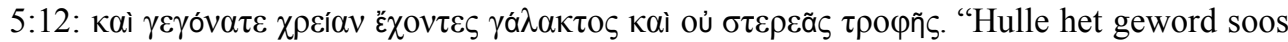
die wat melk nodig het." Die perfektum $\gamma \varepsilon \gamma o ́ v \alpha \tau \varepsilon$ met die partisipium $\check{\varepsilon} \chi 0 v \tau \varepsilon \varsigma$ beteken dat dit 'n staat is, hulle het so geword ("julle het geword") en daar is nog nie 'n verskil nie (vgl. Blass, Debrunner, Rehkopf 1990:287, Zerwick \& Grosvenor 1988:663, Ellingworth \& Nida 1983:102). Die skrywer gebruik die verwyt om sy lesers aan te moedig tot geestelike groei. Soos kinders gewoonlik graag 'groot' wil wees, moet sy lesers verlang daarna om nie meer babas te wees nie, maar geestelik volwasse voedsel te kan hanteer. Hulle het onderwys

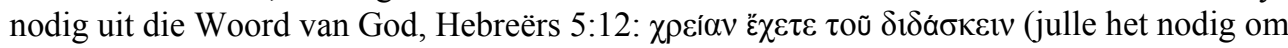
geleer te word). Openbaringskennis is volgens die outeur die antwoord vir geestelike onvolwassenheid. Hulle moet die eerste beginsels van die Woord van God verstaan en internaliseer. Daar is baie dinge wat babas geniet, maar nog nie kan verstaan nie. Sy lesers is babas wat God se heilsplan blykbaar nog nie verstaan nie, hoe hulle saak met God

11 Die gebruik van die seldsame woord of $\delta v \sigma-\varepsilon \rho \mu n ́ v \varepsilon v \tau o \varsigma$ (moeilik om te verduidelik) in Heb 5:11 word veroorsaak deur die ongeleerde staat waarin die lesers hulle bevind. "Die Begründung dafür liegt nicht in der Sache. Es ist nicht so, als bedürfe es einer außerordentlichen Erleuchtung durch Gottes Geist, um das Zeugnis der Apostel zu verstehen... ...Die Begründung dafür, daß "es sich mit Worten schwer erklären läßt, "liegt im Leben der Hörer. Ihr seid stumpf geworden mit euren Ohren," sê Laubach (1967:110) tereg in daardie verband. Volgens Hegermann (1988:126) is dit nie soseer 'n saak van onderwys of slimheid nie, maar van

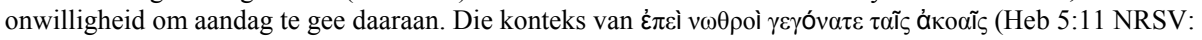
"since you have become dull in understanding") bevestig dat die vernaamste struikelblok vir goeie onderrig nie in die beskikbaarheid of aard van die Woord van God geleë was nie, maar 'n hoor- en verstaanprobleem.

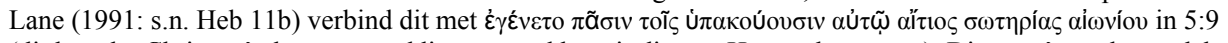
(dit leer dat Christus 'n bron van redding geword het vir die wat Hom gehoorsaam). Dit mag 'n saak van debat wees of hierdie verbinding so sterk is dat die eerste lesers dit wel aangevoel het. Tog is dit vir die konteks van belang dat woorde soos $\pi$ ã

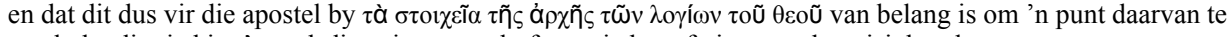
mak dat dit nie hier 'n godsdienstige gevoel of emosie betref nie, maar kennisinhoud. 


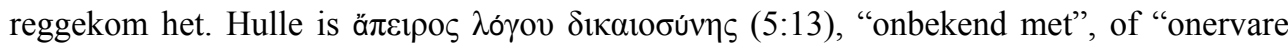
wat die Woord van die geregtigheid betref" (vgl. Blass, Debrunner, Rehkopf 1990:136137). Die genitief dui die spesifieke soort onervarenheid of onbekendheid aan, hulle

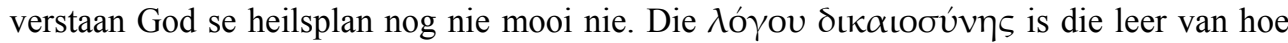
die mens se saak met die Here regkom en hoe hy vrede met God ontvang, vgl. Hughes (1977:191-92).

Tog is daar die moontlikheid van groei vir sy lesers en die skrywer moedig hulle daartoe aan $(5: 14) .{ }^{12}$ Met kennis is dit net soos met kos. 'n Mens begin met melk, maar deur oefening verdra die maag stadigaan baie meer dinge namate die kind grootword. Soos dit ook met kennis van die Woord van God is. Soos hulle groei, sal die lesers kan onderskeid

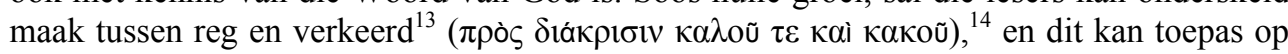
hulle lewe. Die groei is nie vanselfsprekend nie, maar 'n gevolg van 'n oefenproses

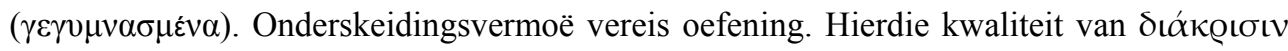
staan antiteties teenoor ăreıڤo (vs.13, vgl. Weiß 1991:333).

\section{Die eerste beginsels van die geopenbaarde Woord}

\section{Tekskritiese opmerkings Heb 5:12}

Die enigste tekskritiese onderwerp van belang by hierdie vers is nie 'n saak van manuskriptradisie nie, maar 'n probleem van interpretasie. Die meeste handskrifte lees die interrogatief $\tau \mid v \alpha$, vgl. die Authorized Version: "ye have need that one teach you again which [ $\tau \mid \mathrm{v} \alpha$ ] be the first principles of the oracles of God" (Metzger 1975:666).

Nestle-Aland doen dit anders en meen dat $\tau$ ıvà gelees moet word: julle het iemand nodig om vir julle die basiese waarhede van die Woord van God opnuut te leer (nagevolg deur bv. die NIV). Hierdie voorkeur vir $\tau$ ivà, is egter gebaseer op net ' $\mathrm{n}$ handjievol handskrifte. ${ }^{15} \mathrm{Al}$

12 In Heb 5:11-14 speel die geestelike groei van gelowiges 'n belangrike rol. Volgens Fensham (1981:48) veronderstel 'n gebrek aan groei ook 'n tekort by die mens wat moes geprobeer het: "Hulle is soos kinders wat nie die volle verantwoordelikheid kan aanvaar nie." Laubach (1967:110) verduidelik hoe hierdie tema van Christelike groei deel is van die leer van die Nuwe Testament: "Der Apostel gründet sich dabei auf die Tatsache, daß es für jeden Christen die Möglichkeit einer gesunden, normalen Entwicklung und Entfaltung im Glaubensleben gibt. Daß NT kennt Wachstumsstufen im geistlichen Leben der Kinder Gottes... ...Es gibt aber auch die Gefahr des inneren Stillstandes, der zum Abfall führen kann. Mangel an Glauben und geistlicher Aufnahmefähigkeit ist ein ünnatürlicher, dem Wachstum des Glaubens widersprechender Vorgang."

13 Geloof, kennis en onderskeidingsvermoë trek saam op. Clemens van Alexandrië Stromateis 1.6.35 (Migne

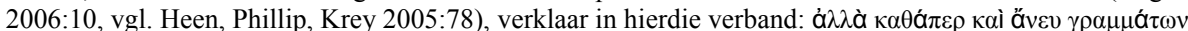

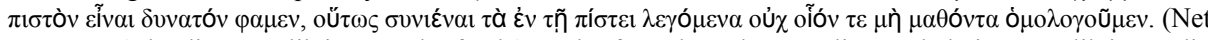
soos ons sê dat dit moontlik is om geloof te hê sonder formele onderwys, dit tog glad nie moontlik is om die geloofsake sonder verdere studie te verstaan nie.) Om waarhede bymekaar te sit en die res te kan verwerp het 'n mens, volgens Clemens, nie genoeg aan 'n eenvoudige geloof nie, maar kort dit geloof wat besig en bereid is om te leer en te studeer.

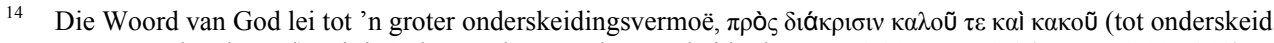
tussen goed en kwaad). Dit is 'n kenmerk van volwassenheid, vlg. Deut 1:39; Jes. 7:16 (Koester 2005:303). Laubach is reg wanneer hy sê dat die onderskeidingsvermoë tussen reg en verkeerd 'n noodsaaklikheid geword het in 'n gevalle skepping. In die oorspronklike, volmaakte wêreld van voor die sondeval was daar geen noodsaak vir onderskeidingsvermoë, of in elk geval nie in die mate waarin dit nou noodsaaklik geraak het nie (Laubach 1967:113)

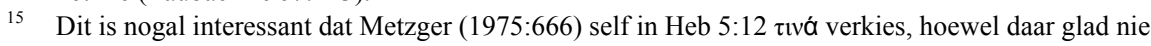
ondersteuning vir sy siening in die handskrifte is nie! Sy komitee het gevoel dat "the indefinite pronoun ( $\tau$ เvá)

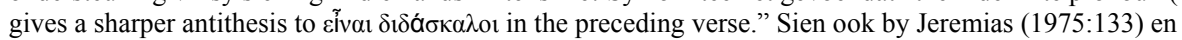
Weiß (1991:331). Egter, die vroeë Christene wat verantwoordelik was vir die deurgee van die Nuwe Testament en wat self nog die taal gepraat het, het egter van die komitee verskil. Die oorweldigende 
die manuskripte wat gewoonlik Nestle-Aland se voorkeur geniet, lees $\tau$ เv $\alpha$ sonder enige

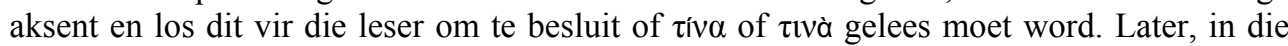
tyd toe aksenttekens algemeen in gebruik gekom het, het nagenoeg almal tiva gelees. In

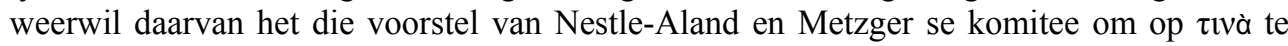
besluit, kritiekloos navolging gekry by die meeste moderne vertalings (Ellingworth \& Nida

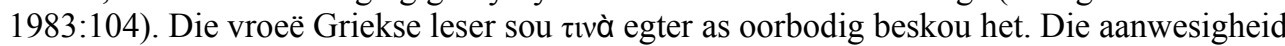

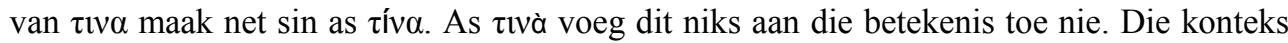
wys glad nie op 'n bepaalde leraar van buite wat nou ingeroep moet word om vir hulle onderrig te gee nie. Die grammatikale konstruksie "julle het nodig om geleer te word," veronderstel klaar dat hulle iemand nodig het om vir hulle onderwys te gee. Die gebruik van $\tau \imath v \alpha$ is egter nie oorbodig wanneer dit die aanduiding is van 'n relatiewe bysin: "julle het nodig om geleer te word wat die eerste beginsels van die Woord van God is." Om hierdie rede verdien die lesing $\tau$ íva die voorkeur.

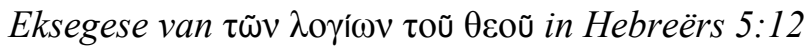

Onder 3.2 het dit reeds duidelik geword dat daar binne 'n algemene konteks van Godsopenbaring spesifieke vermanings volg waarby die outeur die gebrek aan respons van die lesers op God, wat met hulle gepraat het, aan die kaak stel in Hebreërs 5:12. Die outeur raak nogal kwaai met sy lesers en sê dat hulle baie verder gevorder moes gewees het in hulle Christelike kennis en groei. Die partisipium ó $\varphi \varepsilon i \lambda o v \tau \varepsilon \varsigma$ (hoewel julle moes gewees het) word verbind met $\chi \rho \varepsilon i \alpha \nu ~ \varepsilon ̌ \chi \varepsilon \tau \varepsilon$, (het julle nodig). Hulle het nie voldoen aan die geestelike verwagtings nie: "Hoewel julle reeds leraars moes gewees het, ${ }^{16}$ het julle nodig om opnuut geleer te word wat die basiese beginsels van die Woord van God is." Hoewel die lesers volgens die pad wat hulle gekom het reeds self in staat moes gewees het om ander te onderrig in die Christelike leer, is hulle nie daartoe in staat nie. Hulle word opgeroep om terug te keer na die bron en om aan die fondasies van hulle geloofskennis te werk (Bauer \& Aland 1988:1534-1535; Laubach 1967:111).

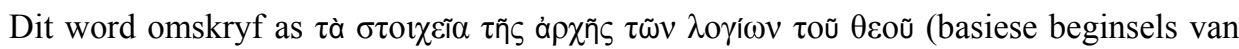
God se orakels). Zerwick \& Grosvenor (1988:663) het 'n goeie vertaling: "the elementary principles of God's oracles". Koester (2005:301) volg dit na in sy voorstel: "the most elementary matters of the oracles of God." As openbaringswoorde van God het die orakels gesag in hulle eie reg. Van Oyen (1962:84): "De eerste beginselen van de uitspraken Gods." ${ }^{, 17}$ Schunack (2002) praat in verband met Heb 5:12 van: "die Elemente des (grundlegenden) Anfangs der Worte Gottes." Fensham (1981:49) verwys in hierdie verband na: "Grondwaarhede van die woorde van God."

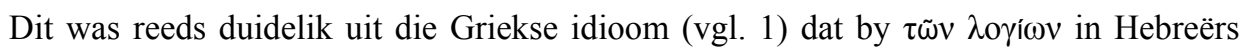
5:12 nie bloot woorde ter sprake is nie, maar die spesifieke uitdrukking vir Godsprake of orakels. Dit gaan oor openbaringswoorde. Die meervoud met die gebruik van die lidwoord

tekskritiese bewyse is ten gunste van 'n natuurlike interrogatief ( $\tau$ ívo): "Julle het nodig dat iemand julle leer hoe die eerste beginsels van God se openbaringswoorde lyk."

16 Die skrywer verwyt sy lesers dat hulle self al leraars moes gewees het teen hierdie tyd. In hierdie konteks

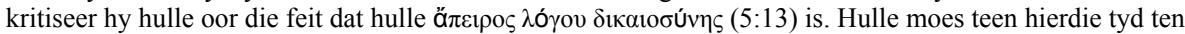
minste die basiese beginsels van die Christelike leer verstaan en geïnternaliseer het. Die uitdrukking

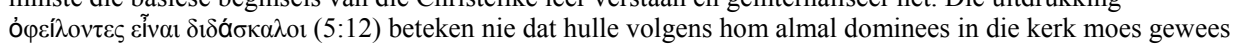
het nie (Vgl. Hughes (1977:190), Ellingworth \& Nida (1983:104), Laubach (1967:110,11).

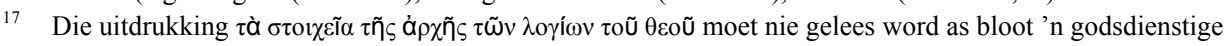
teorie wat die lesers aanvaar nie. Dit gaan om 'n verhouding met die lewende God, 'n nadere verstaan van sy Woord en die verkondiging daarvan aan ander. Vgl. Ps 95, Heb 3:7, 4:2, $13: 22$ (Koester 2001:280). 
dui aan dat dit gaan om 'n versameling of die verskynsel van Godsprake. Die goddelike oorsprong word dan nog verder versterk deur $\tau$ oũ $\theta$ \&oũ. Binne die filologiese konteks van Hebreërs 5:12 verwys hierdie Godspraak na die Woord van God op 'n algemene manier. Laubach (1967:111) stem saam en vertaal dit baie mooi: "allerersten Grundlagen des Wortes Gottes."

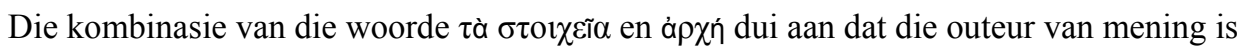
dat dit om regte basiese kennis gaan, wat maar beperk is. Maar daardie beperkte kennis uit die kleuterskool van die Woord van God is volgens hom van groot belang. ${ }^{18}$ Die feit dat hy

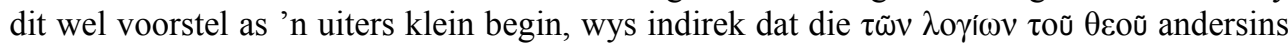
nog baie te sê het. Die vergelyking met melk en vaste kos dui op die noodsaak en genoegsaamheid van die Godsprake. Sonder melk sterf die babas en sonder deeglike kos raak die mens gebrekkig. Selfs die basiese beginsels van die Godsprake is soos melk vir babas, wat hulle help om te oorleef. Gelowiges is egter nie veronderstel om babas te bly nie. Soos hulle groei, moet hulle vaste spyse begin eet en meer kennis kry van die Woord van God, sodat hulle daarvolgens kan optree. Hoewel die uitdrukking "Woord van God" in hierdie verband nie die Skrifte van Moses, die Profete of selfs die Apostels hoef uit te sluit nie, is

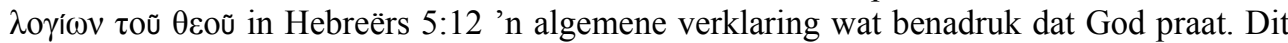
is die geopenbaarde Woord van God. Om hierdie rede is dit op dinamies-ekwivalente wyse ook wel vertaal as "the ABC of God's revelation to men" (JB Phillips, cf. Ellingworth \& Nida 1983:104) of as "the ABC of God's oracles" (cf. Lane 1991:s.n. Heb 5:12).

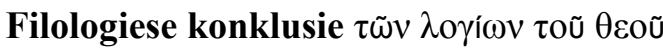

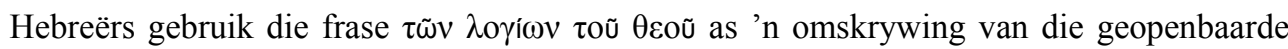
Woord van God. Die konteks van Hebreërs 2:12 binne die dokument is een van 'n persoonlike verhouding tussen God en die mensheid, waarby die Here uitreik na die mens met sy genade en praat deur sy Woord. Die Godsprake is die Here se instrument om sy verhouding met die mens aan die gang te hou en te versterk met geestelike groei tot

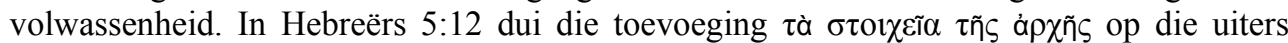
basiese kennis of verstaan van hierdie Godsprake, 'n basiese kennisname van God se uitsprake. Volgens die outeur het die toepassing, sèlfs van hierdie basiese kennis die potensiaal om die lewe van gelowiges te verander en geestelik toe te rus.

Die gebruik van $\lambda$ oyíw as sulks impliseer reeds 'n goddelike bron, maar dit word nog versterk deur die toevoeging $\tau$ oũ $\theta \varepsilon$ so. Die bron van die orakels is, filologies binne Hebreërs 5:12, maar ook binne die konteks van Hebreërs, 'n alwetende en magtige God wat

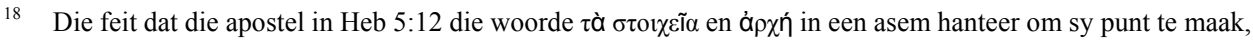
wys hy praat baie ernstig met hulle. Sy lesers het nog nie eers die mees basiese goed onder die knie nie: "die eenvoudigste waarhede wat aan hulle verkondig is, weer oorgeleer moet word. Hulle moes onderwysers wees vanweë die lang onderrig wat hulle ontvang het, nou is hulle nog leerlinge in die beginstadium van hulle ontwikkeling. Hulle het dus in hul geestelike eksamen gesak" (Fensham 1981:49). Schunack (2002: ad Heb 5:12) veronderstel dat die apostel hierdie kombinasie van woorde gebruik het om aan te dui dat hy sowel

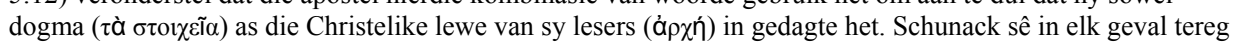
dat dit nie om 'n bloot intellektuele instemming gaan nie, maar om 'n regte verhouding tot God wat hom en sy Woord ernstig neem: "Insgesammt ist wohl gemeint: Die Adresaten haben wieder nötig, mit dem grundlegenden Anfang des Redes Gottes anzufangen- nicht um intellektuell darüber hinaus-, sondern existenziell und praktisch in ihn hineinzukommen." Hoewel Schunack se siening teologies sin maak, is daar

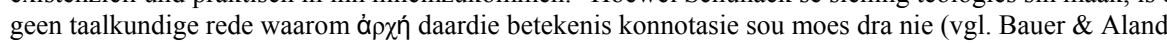

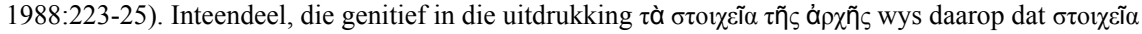
gekwalifiseer word deur á $\rho \chi \tilde{n} \varsigma$, nie dat die twee terme onderskeie verwysings sou bevat na leer en lewe nie. 
die voortou geneem het om uit te reik na die mensheid, en wat kommunikeer met en handel op sy Woord.

As 'n mens net die basiese beginsels van God se uitsprake ter harte neem, is daar hoop

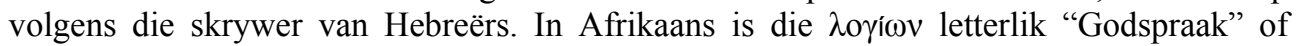
"Openbaringswoorde/orakels". As sulks is daar taalkundig reeds sprake van die konsep van openbaring, 'n meervoud wat die outeur hier kollektief gebruik.

Hoewel die hemelse oorsprong van die woorde deur die spesifieke keuse vir $\lambda \mathrm{o} \gamma i \omega \mathrm{v}$ reeds duidelik is, vind die outeur dit tog belangrik om dit te beklemtoon met die toevoeging

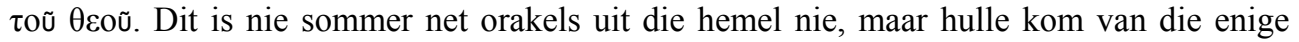
ware God af. Hy praat reeds met die mens vanaf die Skepping en uiteindelik deur sy Seun. Dit gaan om 'n openbaringsproses wat die eeue omspan.

Die outeur van Hebreërs het daarmee 'n boodskap, vir sy lesers toe en nou. Geloof is nie maar bloot 'n saak van gevoel en menslike gedagtes oor 'n opperwese nie. Vir hom is dit nie die mense benede op aarde wat op grond van geestelike gevoelens en spirituele tradisies gesaghebbende uitsprake oor godsdiens en teologie doen nie. Dit gaan volgens die skrywer van Hebreërs oor God in die hemel wat spesifiek praat met die mens op aarde. Wanneer dit regtig so is, indien die Here se stem waarlik ${ }^{19}$ klink in Geskrifte wat deur sy Kerk ontvang is, dan mag die gelowiges volgens Hebreërs nie verskonings uitdink om dom te kan bly nie. Lettergeleerdheid en Godgeleerdheid gaan goed saam (Theron 2002:156158). Die skrywer soek geen permanente babas in die kerk nie, wat maar net wil 'aanbid' en hemel toe gaan. Volgens hom het Christene die plig om te luister en te groei in kennis van God se openbaring. Kennis van sy geopenbaarde orakels is 'n elementêre voorwaarde vir kerkwees en Christendom. Gevolglik word die volgende vertaling van die betrokke deel

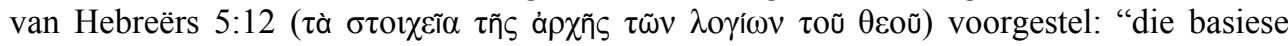
beginsels van die geopenbaarde Woord van God".

\section{AANGEHAALDE BRONNE}

Bauer, W, K Aland, B Aland 1988. Wörterbuch zum Neuen Testament. 6, völlig neu bearbeitete Auflage. Berlin: Walter de Gruyter.

Bette, JC, G Van Den Brink, H Courtz, GA Van Veelen 1988. De brief van Paulus aan de Hebreën. (Studiebijbel) Soest: In de Ruimte.

Blass, F, A Debrunner, F Rehkopf 1990. Grammatik des Neutestamentlichen Griechish. Göttingen: VandenHoeck \& Ruprecht.

Boice, JM 1991. Justification by faith, Romans 1:1-4:25. Grand Rapids: Baker Book House.

Dunn, JDG1988. Romans 1-8. (Word Biblical Commentary) Waco: Word.

19 Gerricke (2009:790-791) waarsku, op grond van die aanhalings uit die Psalms in Hebreërs, tereg teen die inlees van 'n wiskundige waarheidsbegrip in die teks. Tog moet 'n mens verreken dat Hebreërs volgens Clemens Romanus, Pantaenus van Alexandrië en Origenes 'n Griekse vertaling van Paulus se Hebreeus deur Lukas betref. Dit kon aangestuur gewees het deur Lukas en/of Timoteüs (vgl. Zuiddam 2010). Die outestamentiese verwysings in Hebreërs kom egter nie uit die Masorete-teks nie, maar uit die Septuagint. Ook die wiskundige waarheidsgehalte van Hebreërs is waarskynlik groter as algemeen aangeneem, veral as net die vroeë konsonante en nie die laat Judaïserende vokale van die masora in ag geneem word nie. 
Ellingworth, P, EA Nida 1983. A translator's handbook on the letter to the Hebrews. United Bible Societies.

Fitzmyer, JA 1993. Romans. A new translation with introduction and commentary. (The Anchor Bible) London: Doubleday.

Fensham, FC 1981. Die brief aan die Hebreërs. Kaapstad: NG Kerk Uitgewers.

Gericke, JW 2009. Philosophical theories of truth and the logical status of intra-Biblical fallacies of contextomy. In die Skriflig, Vol 43(4):777-792.

Heen, E, Krey, PD 2005. Hebrews. (Ancient Christian Commentary on Scripture). Downers Grove: Inter Varsity Press.

Hegermann, H 1988. Der Brief an die Hebräer. (Theologisches Handkommentar zum Neuen Testament) Berlin: Evangelische Verlagsanstalt.

Hughes, PE 1977. A commentary on the Epistle to the Hebrews. Grand Rapids: Eerdmans.

Jeremias, J, A Strobel 1975. Die Briefe an Timotheus und Titus. Der Brief an die Hebräer. (Das Neue Testament Deutsch) Göttingen: Vandenhoeck \& Ruprecht.

Karrer, M 2002. Der Brief an die Hebräer. (Ökumenischer Taschenbuchkommentar zum Neuen Testament) Gütersloh: Gerd Mohn.

Koester, CR 2001. Hebrews. (The Anchor Bible) New York: Doubleday.

Lane, W 1991. Hebrews 1-8. (Word Biblical Commentary) Waco: Word.

Laubach, F 1967 Der Brief an die Hebräer. (Wuppertaler Studienbibel) Wuppertal: Brockhaus Verlag.

Lekkerkerker, AFN 1962. De brief van Paulus aan de Romeinen.(De Prediking van het Nieuwe Testament) Nijkerk: Callenbach.

Liddell, HG, R Scott 1996. A Greek-English Lexicon. Compiled by Henry George Liddell and Robert Scott. Revised and augmented throughout by Sir Henry Stuart Jones with the assistance of Roderick McKenzie and with the co-operation of many scholars. With a revised supplement 1996. Oxford. Clarendon Press.

Metzger, BM 1975. A textual commentary on the Greek New Testament. A companion volume to the United Bible Societies' Greek New Testament (third edition). Stuttgart: United Bible Societies.

Migne, JP 2006. Patrologiae Cursus Completus (Seu Bibliotheca Universalis... Omnium S.S. Patrum Doctorum, Scriptorumque Ecclesiasticorum.) Series Graeca. By Jacques Paul Migne. Mytilene: Cultural Heritage Management Lab, University of the Aegean.

Nestle, E, K Aland 1988. Novum Testamentum Graece. Stuttgart: Deutsche Bibelgesellschaft.

Pirot, L, A Clamer 1946. Épitre de la captivité, épitres aux Thessaloniciens, épitres pastorals, épitre a Philémon, épitre aux Hébreux, épitre catholiques, Apocalypse. (La Sainte Bible, texte Latin et traduction Française d'après les texts originaux avec un commentaire exégétique et théologique). Paris: Letouzey et Ané.

Schunack, G 2002. Der Hebräerbrief. Zürich: Theologischer Verlag.

Theron, PF 2002. Die oudheid van die letter en die nuutheid van die Gees. Enkele opmerkings oor die Skrif as lewende Woord. Acta Theologica: Essentialia et Hodierna, Supplementum 3:150-168.

Spicq, C 1977. L'Épitre aux Hebreux. (Sources Bibliques) Paris: Librairie Lecoffre. 
Van Oyen, H 1962. De brief aan de Hebreeën. (De Prediking van het Nieuwe Testament) Nijkerk: Callenbach.

Weib, H-F 1991. Der Brief an die Hebräer. (Kritisch-exegetischer Kommentar über das Neue Testament) Göttingen: Vandenhoeck \& Ruprecht.

Zerwick, M, M Grosvenor 1988. A grammatical analysis of the Greek New Testament. Roma: Papal Bible Institute (Editrice Pontificio Institutio Biblico).

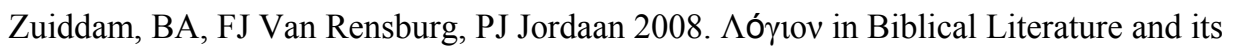
implications for Christian Scholarship. In: Acta Patristica et Byzantina (19):379394.

Zuiddam, BA 2010. Volgens Origenes schreef Paulus de Hebreeënbrief. Reformatorisch Dagblad,15-10-2010.Online:

http://www.refdag.nl/opinie/opinie/volgens_origenes_schreef_paulus_de_hebreeenb rief_1_509096. 